\title{
A Histological Study on the Endocrine and Exocrine Glands of Fish by Bowie's Stain*1
}

\author{
Mikio OGURI*2 \\ (Received February 15, 1979)
}

\begin{abstract}
Using Bowie's and other staining methods, histological examinations were made on seven kinds of endocrine and three kinds of exocrine glands of fish, and the following results were obtained. Bowie's method is recommended for demonstration of the cellular secretory granules in BROCKMANN body, corpuscle of STANNIUS, renal juxtaglomerular cells, pancreatic acinar cells, and gastric zymogenic cells. Use of this method for differentiation gave excellent results in the secretory granules of A- and B-cells of Brockmann body. Furthermore, Bowie's method is suitable for staining the neuro-secretory inclusion in the preoptic neurosecretory cells, STH- and ACTH-cells of pituitary gland, and also colloid in the lumen of thyroid follicle. However, this method is not applicable for staining the chromaffin and interrenal cells of the adrenal gland, cells of ultimobranchial gland, and also the epidermal mucous cells of fish skin.
\end{abstract}

Bowie's staining method uses a neutral dye made by precipitating aqueous Biebrich scarlet by cautiously adding aqueous ethyl violet. This neutral dye was first applied by WILSON" to stain selectively the granules of juxtaglomerular cells of rat kidney. Thereafter, this Bowie's method has been widely employed in the investigation of juxtaglomerular cells of mammalian kidneys. ${ }^{2,3 \text {; }}$ Furthermore, recently Bowie's method has been used in the studies of renal juxtaglomerular cells in lower vertebrates, and the presence of the cells has been ascertained in the teleostean and holocephalian kidneys. ${ }^{4-81}$

Originally, however, this staining method was devised by BowIE ${ }^{910)}$ for demonstration of the secretory granules in endocrine pancreatic cells and the pepsinogen granules in gastric chief cells. This suggests that Bowie's method is applicable for staining various types of secretory cells, though the method has been exclusively employed to stain selectively the granules in renal juxtaglomerular cells. To ascertain this suggestion, I did histological investigation on the various endocrine and exocrine glands of fish using Bowie's method.

\section{Materials and Methods}

The glandular tissues investigated in the present study are seven kinds of endocrine gland and three kinds of exocrine one from various species of fish.
The names of these glands and fish species are listed in Table 1. Zenker-formol fluid was used as fixing one for these tissues except for the pituitary gland inclusive of hypothalamic region. The latter gland was fixed in Bouin-Hollandesublimate fluid.

After fixing, these tissues were dehydrated in ethanol, embedded in paraffin, and sectioned at a thickness of $7 \mu \mathrm{m}$. The sections were stained with Bowie's method and examined by light microscopy. In addition, several sections were stained at need by the following staining methods; Mayer's acid hemalum-eosin, PAS-Mayer's acid hemalum, and Gomori's chrome hematoxylin-phloxine.

\section{Results of Observation}

The following results were obtained from the present microscopic examination. Brockmann body: Three cell types (A-, B-, and D-cells) are distinguished in the BrockMANN body of carp, Cyprinus carpio. ${ }^{213}$ Applying Bowie's staining method to the carp BRocKMANN body, three cell types were also demonstrable. Secretory granules of first and second cell types stained purplish red and blue by this method, respectively (Fig. 1), whereas third cell type included no such stainable granules. After examination, sections were destained in $95 \%$ ethanol and then restained by Gomori's chrome hematoxylin and phloxine.

\footnotetext{
*1 The outline of this report was presented at the annual meeting of the Japanese Society of Scientific Fisheries, Tokyo, Japan, April, 1979.

*2 Fisheries Laboratory, Faculty of Agriculture, Nagoya University, Chikusaku, Nagoya 464 (小槑幹郎: 名古屋大学農学部水産学教室).
} 
Table 1. Histological examination on the various secretory cell types of fishes by Bowie's stain

\begin{tabular}{|c|c|c|}
\hline Gland & Fish species & Bowie's stain \\
\hline \multicolumn{3}{|l|}{ Endocrine: } \\
\hline Adrenal gland & Toadfish, Opsanus tau & Unstainable \\
\hline BROCKMANN bOdy & Carp, Cyprinus carpio & $\begin{array}{l}\text { Stainable: A-cell granules (purplish red), B-cell } \\
\text { granules (blue) }\end{array}$ \\
\hline Corpuscle of Stannius & $\begin{array}{l}\text { Kizihata, Epinephelus } \\
\text { akaara }\end{array}$ & Stainable: Secretory granules (reddish purple) \\
\hline $\begin{array}{l}\text { Pituitary gland inclusive } \\
\text { of hypothalamus }\end{array}$ & Eel, Anguilla japonica & $\begin{array}{l}\text { Stainable: Cytoplasm of STH- and ACTH-cells and } \\
\text { cytoplasmic inclusion in preoptic neurosecretory } \\
\text { cells (reddish purple) }\end{array}$ \\
\hline $\begin{array}{l}\text { Renal juxtaglomerular } \\
\text { cells }\end{array}$ & $\begin{array}{l}\text { Rabbitfish, Chimaera } \\
\text { monstrosa }\end{array}$ & Stainable: JG granules (bluish purple) \\
\hline Thyroid gland & Medaka, Oryzias latipes & Stainable: Colloid in follicle (purple to reddish purple) \\
\hline $\begin{array}{l}\text { Ultimobranchial gland } \\
\text { Exocrine: }\end{array}$ & Goldfish, Carassius auratus & Unstainable \\
\hline Exocrine pancreas & Dochizame, Triakis scyllia & Stainable: Zymogen granules (purple to reddish purple) \\
\hline Gastric gland & $\begin{array}{l}\text { Rainbow trout, Salmo } \\
\text { gairdneri }\end{array}$ & Stainable: Granules of Zymogenic cells (bluish purple) \\
\hline Mucous cells of skin & Eel, Anguilla japonica & Unstainable \\
\hline
\end{tabular}

The secretory granules of first and second cell types stained also red and blue by this stain, respectively. Consequently, I identified the purplish red staining cells as A cells and blue ones as B cells.

Corpuscle of Stannius

This gland of Kizihata, Epinephelus akaara, contains abundantly the coarse acidophilic granules stainable with eosin or phloxine. These secretory granules stained distinctly reddish purple by Bowie's method (Fig. 2).

\section{Pituitary Gland Inclusive of Hypothalamus}

Glandular cell types of eel pituitary gland were established by OtrvereaU, ${ }^{12}$ ' using European eel, Anguilla anguilla. During the examination on the gland of Japanese eel, A. japonica, I noticed that many secretory cells in proximal pars distalis appeared distinctly deep reddish purple when stained by Bowie's method (Fig. 3). After examination, sections were destained in $95 \%$ ethanol and then restained by Mayer's acid hemalum and eosin, or Gomori's chrome hematoxylin and phloxine. Then these Bowie-positive cells appeared as acidophilic cells. Accordingly, these cells were identified as STH-cells.

Furthermore, the cytoplasm of ACTH-cells locating in the rostral pars distalis stained reddish purple by Bowie's method (Fig. 4). But the colouration of reddish purple in ACTH-cells was more weakly than that in STH-cells. These ACTH-cells were located in palisade-like arrangement, being contiguous to the neurohypophysis (Fig. 4).

During the course of this examination, I noticed also that the neurosecretory inclusion observed in the neurosecretory cells of preoptic nucleus stained reddish purple by Bowie's method (Fig. 5). These inclusions were also observable in the sections stained by Gomori's chrome hematoxylin and phloxine.

\section{Renal Juxtaglomerular Cells}

These cells in the rabbitfish, Chimaera monstrosa, contain many granules staining selectively bluish purple by Bowie's method (Fig. 6). Detailed observations were reported in a previous paper ${ }^{81}$ on the presence of juxtaglomerular cells in holocephalian kidney.

\section{Exocrine Pancreas}

As examining tissue, I employed the exocrine pancreas of Dochizame, Triakis scyllia. The zymogen granules in the pancreatic acinar cells of this shark stained intensely red by Gomori's chrome hematoxylin and phloxine. The granules stained also selectively purple to reddish purple by Bowie's method (Fig. 7).

\section{Gastric Gland}

The stomach of rainbow trout,Salmo gairdneri, was used for the examination of gastric gland. The stomach of this fish consists of three regions; cardiac, transitional and pyloric regions. ${ }^{13 !}$ In the present observation, the zymogenic cells of cardiac stomach were examined exclusively. The granules of these cells stained red by Gomori's chrome hematoxylin and phloxine. The granules appeared as bluish purple by Bowie's stain (Fig. 8).

\section{Other Glands}

As for adrenal gland, no secretory granules stainable by Bowie's method were observed in the chromaffin cells and also in the interrenal 
ones of toadfish, Opsanus tau (Table 1). Also, the follicular epithelial cells of thyroid gland in Medaka, Oryzias latipes, did not contain the secretory granules stained by Bowie's method. However, the colloid in the lumen of thyroid follicle stained purple to reddish purple by this method (Table 1). As the examining ultimobranchial gland, the gland of goldfish, Carassius auratus, was employed, because it is well-developed glandular tissue, locating in the connective tissue, ventral to the oesophagus, and caudad to the sinus venosus. ${ }^{11}$ However, no secretory granules stainable with Bowie's method were detected in the goldfish tissue (Table 1). For the histological examination of mucous cells, the epidermis of eel, $A$. japonica, is suitable, because many large mucous cells are included in it. These mucous cells were strongly PAS-positive, but they remained unstained by Bowie's method (Table 1).

\section{Discussion}

In the present study, the secretory granules in the corpuscle of Stannius from Kizihata, $E$. akaara, were demonstrated distinctly by Bowie's method. Also, in the previous papers, ${ }^{15,16)}$ the secretory granules in the corpuscular cells of StanNIUS have been ascertained to be stainable with Bowie's method, using the following six teleostean species, goldfish, $C$. auratus, rainbow trout, $S$. gairdneri, eel, $A$. japonica, Kue, Epinephelus moara, yellowtail, Seriola quinqueradiata, and angler, Lophius litulon. Ultrastructurally, the cells in the corpuscle of Stannius have been ascertained to resemble those of pancreatic acinar cells. ${ }^{17)}$ Furthermore, fine structure of gastric zymogenic cells is known to be very similar to that of the pancreatic acinar cells. ${ }^{18)}$ Accordingly, it seems reasonably that the same positive staining results were obtained in these three types of secretory cells by Bowie's method.

The present examination on carp BROCKMANN body revealed that the secretory granules of Aand B-cells stained purplish red and blue by Bowie's method, respectively. Using another teleost, Neomaenis griseus, BowIE" had obtained the same staining result in the BrockMANN body fixed in Zenker's fluid without acetic acid. Furthermore, he noticed that the granules of A- and B-cells in the BROCKMANN body of this fish stained differently blue and purple by Bowie's method respectively, when fixed in Zenker's fluid containing acetic acid. In the present investigation on the pituitary gland inclusive of hypothalamic region, Bouin-Hollandesublimate fluid was used for fixation. This fluid contains acetic acid as a component. As described above, STH-cells were demonstrated most distinctly Bowie's method among the several cell types in the eel pituitary gland fixed in the fluid. Also, ACTH-cells and neurosecretory inclusion of preoptic neurosecretory cells appeared reddish purple in colour by the method. However, if Zenkerformol fluid was used for tissue fixation, these cells and the inclusion might appear in different staining colouration by Bowie's method.

The same staining finding was observed between the secretory granules in the juxtaglomerular cells of rabbitfish, $C$. monstrosa, and those in the gastric zymogenic cells of rainbow trout, $S$. gairdneri. Both kinds of secretory granules stained identically bluish purple by Bowie's method, though the gastric zymogeniz cells produce pepsin, a digestive enzyme, whereas the juxtaglomerular cells secrete renin, angiotensin I-producing enzyme. This indicates that Bowie's stain is not specific staining method for the identification of juxtaglomerular cell granules.

In conclusion, the present investigation revealed that several kinds of secretory granules in glandular cells were stainable by Bowie's method, in addition to the granules of renal juxtaglomerular cells. Therefore, Bowie's stain is applicable for the histological examination on the secretory granules not only in the renal juxtaglomerular cells, but also in other glandular cells.

\section{Acknowledgement}

I wish to thank Mrs. Kiyoko KogA for her excellent technical assistance to the present study.

\section{References}

1) W. Wilson; Anat. Rec., 112, 497-507 (1952).

2) J. A. Pitcock and P. M. Hartroft: $A m$. $J$. Path., 34, 863-883 (1958).

3) H. Matsuhashi, T. Nishida, and K. Mochizuki: Jap. J. vet. Sci., 39, 379-388 (1977).

4) S. V. Capréol and L. E. Sutherland: Can. J. Zool., 46, 249-256 (1968).

5) M. OGuri and H. Sokabe: Bull. Japan. Soc. Sci. Fish., 34, 882-888 (1968).

6) V. G. Krishnamurthy and H. A. Bern: Gen. Comp. Endocrinol., 13, 313-335 (1969).

7) M. Oguri, M. Ogawa, and H. Sokabe: Bull. Japan. Soc. Sci. Fish., 38, 195-200 (1972).

8) M. OGuri: Gen. Comp. Endocrinol., 36, 170 
173 (1978).

9) D. J. Bowle: Anat. Rec., 29, 57-73 (1924).

10) D. J. BowIE: Anat. Rec., 64, 357-367 (1936).

11) A. Watanabe: Arch. hist. jap., 19, 279-330 (1960).

12) M. Olivereau: Z. Zellforsch. mikrosk. Anat., 80, 286-306 (1967).

13) E. L. Weinreb and N. M. Bilstad: Copeia, 1955, 194-204 (1955).

14) M. OGuri: Bull. Japan. Soc. Sci. Fish., 39, 851-858 (1973).
15) H. Sokabe, H. Nishimura, M. Ogawa and $M$. OGURI: Gen. Comp. Endocrinol., 14, 510-516 (1970).

16) M. Oguri and H. SokABe: Bull. Japan. Soc. Sci. Fish., 40, 545-549 (1974).

17) M. OGur1: Bull. Japan. Soc. Sci. Fish., 32, 903-908 (1966).

18) W. Bloom and D. W. FawcetT: A Textbook of Histology, 9th ed., W. B. Saunders, Philadelphia, 1968, pp. 549-554,

\section{Explanation of Plate 1}

Fig. 1. Glandular cells in the Brockmann body of carp, Cyprinus carpio. $\times 2150$ Ac and Bc indicate A- and B-cells, respectively.

Fig. 2. Secretory granules in the cells of Stannius corpuscle of Kizihata, Epinephelus akaara. $\times 1700$

Fig. 3. STH-cells in the proximal pars distalis of eel, Anguilla japonica. $\times 810$ Deeply stained cells indicate STH-cells.

Fig. 4. ACTH-cells in the rostral pars distalis of eel, A, japonica. $\times 570$ Arrows indicate the palisade-like arrangement of ACTH-cells. Nh: neurohypophysis, Pc: prolactin cells.

Fig. 5. Neurosecretory cells in the preoptic nucleus of eel, $A$. japonica. $\times 570$ Arrows indicate neurosecretory inclusion in the cytoplasm.

Fig. 6. Renal juxtaglomerular cells of rabbitfish, Chimaera monstrosa. $\times 810$ Arrows indicate juxtaglomerular cell granules in the afferent arteriole. Gl: glomerulus.

Fig. 7. Pancreatic acinar cells of Dochizame, Triakis scyllia. $\quad \times 570$

Fig. 8. Zymogenic cells in the cardiac stomach of rainbow trout, Salmo gairdneri. $\times 1200$ Figs. 1, 2 and 6-8: Zenker-formol fixation and Bowie's stain.

Figs. 3-5: Bouin-Hollande-sublimate fixation and Bowie's stain. 
Plate 1

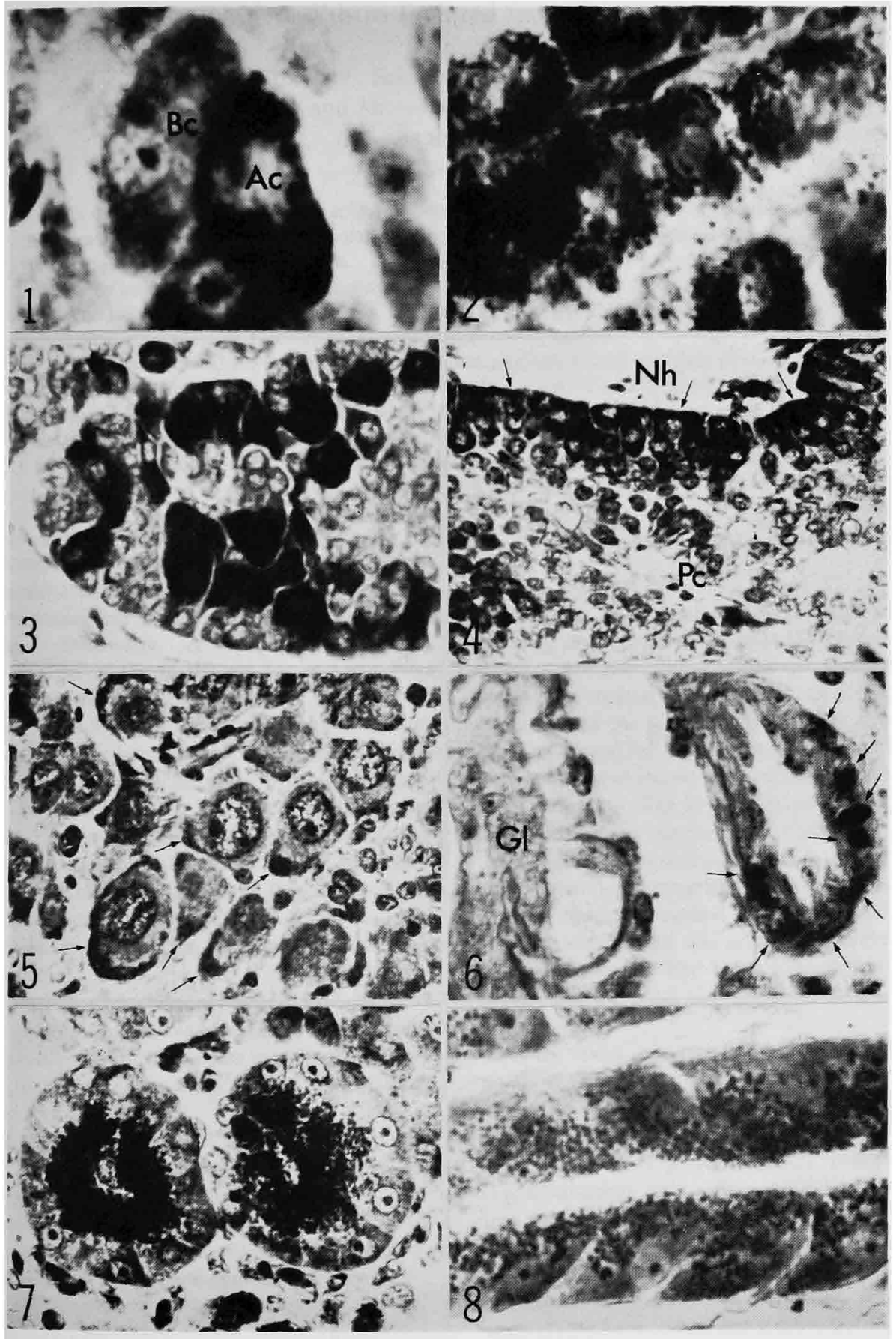

